\title{
THE EFFECT OF PERCEIVED USEFULNESS AND PERCEIVED EASE OF USE WHATSAPP ON EMPLOYEE ENGAGEMENT AND EMPLOYEE PERFORMANCE
}

\author{
Dedi Iswanto ${ }^{*}$, Ayi Ahadiat' ${ }^{1}$, Ribhan ${ }^{1}$ \\ ${ }^{1}$ Faculty of Economics and Bussines, University of Lampung,Indonesia \\ *dedi.isw@hotmail.com
}

\begin{abstract}
Various studies were conducted to reveal two important and interesting things from employees, namely employee engagement and employee performance. This study aims to observe the effect of using WhatsApp among employees on employee engagement and employee performance. Two main variables of the Technology Acceptance Model theory, namely perceived usefulness and perceived ease of use are used as independent latent variables on employee engagement and employee performance which are the dependent variables. The respondents used in this study are 142 peoples, all of whom are the employees at state universities in Lampung. Partial Least Squares- Structural Equation Modeling (PLS-SEM) analysis are used to examine the structure model and the influence between latent variables and to test the hypothesis. The validity and reliability tests show valid and reliable results. The results show that in the use of WhatsApp, perceived ease of use is an important variable and is statistically proven to significantly affect employee engagement and employee performance. Meanwhile, the two TAM variables have also been shown to have a significant effect on employee engagement.
\end{abstract}

Keyword: Employee Engagement, Employee Performance, Perceived Ease of Use, Perceived Usefulness, WhatsApp.

Copyright (c) 2020, International Journal of Economics, Business and Entrepreneurship | IJEBE | FEB-UNILA

\section{INTRODUCTION}

Today, many organizations in the world are faced with efforts to uncover and develop the potential of their employees that can be utilized to increase productivity in their workplace. The term employee engagement, which was introduced by Kahn (1990) as a concept of involvement in the form of optimal utilization of organizational members for their own work roles, has become one of the potentials that has been considered and has been widely explored in various studies (Anitha, 2014).

In the last 15 years, employee engagement has replaced job satisfaction as the most important attitude in the workplace (Hughes, 2012). But it is difficult to implement, even on a global scale. Gallup (2017) reports that only 15 percent of the world's employees are engaged in their workplace. In fact, engagement can make employees willing to exercise discretion to complete important tasks in order to achieve organizational goals (Kanexa, 2012), employees will be more productive and experience better well-being, both inside and outside the workplace (Byrne and MacDonagh, 2018).

Employee engagement is often associated with company performance and productivity. Organizations in following the demands of the industrial revolution 4.0 requires employees who are highly engaged. As stated by Hickey;AON(2018), organizations requires a highly engaged workforce to delivers the innovation, agility and performance. Anitha (2014), revealed that employee engagement has a significant impact on employee performance. As described by Motyka (2018), the results of semantic studies that show various types of studies that prove the relationship and importance of employee engagement and performance.

Various studies reveal that employee engagement and employee performance can be influenced by the use of a technology product. One of them is social media, which refers to Web 2.0-based Internet 
applications with the principle of generating content streams from users. The flow that occurs creates a traffic of content needs and becomes the most important essence of its existence, which according to Obar and Wildman (2015) is referred to as the lifeblood of social media.

Aberdeen Group (2008) in Parry and Solidoro (2013), revealed that organizations that use social media could increase employee engagement by 18 percent, compared to an increase of only 1 percent in organizations without social media implementation. Social media allows the employees to have a direct relationship with top management and share their personal opinions, which according to research is an antecedent of engagement (Ruck et al., 2017 dalam Ewing et al., 2019); promotes the formation of employee social capital and has been shown to positively affect employee performance (Cao et al., 2016).

One of the messaging applications (messenger) with the principle of social media through Web 2.0 internet technology which is popular today is WhatsApp. Compared to SMS, WhatsApp can handle more social and natural interactions resulting in a higher frequency of chat, planning or coordination, and group communication (Church and de Oliveira, 2013). WhatsApp is rapidly replacing the role of short message service (SMS) in many countries around the world. The survey agency Statista reports around 1.6 billion users that are actively involved in using WhatsApp in 180 countries (Statista.com, 2019). Furthermore, the daily active users in the first quarter of 2019 reached more than 500 million. In Indonesia, WhatsApp also became the most popular social media messaging application in 2019. From the 124 million active internet users in Indonesia, 83 percent of them use WhatsApp (Wearesocial and Hootsuite, 2019).

Acceptance of WhatsApp in Indonesia, researched by Aulia, E.D. (2018) uses the TAM theory. As a result, the two main variables of TAM, namely perceived ease of use and perceived usefulness are well received, which infer that WhatsApp is easy to use and useful for its users.

With the TAM approach, the use of WhatsApp has proven to have a positive and significant effect on employee job performance through 2 TAM variables, namely perceived usefulness and perceived ease of use (Kassim et al., 2018). Meanwhile, Ariffin and Omar's research (2018) proves that the perceived ease of use using WhatsApp among employees has an effect on employee engagement.

\section{METHODS}

This study uses primary data from the direct questionnaires conducted by the respondents. Questionnaires were distributed through online surveys, with questions consisting of sections on Demographics, WhatsApp Usage, WhatsApp TAM Needs Patterns, Employee Engagement, and Employee Performance. There are choice available with nominal, ordinal, and interval categories.

The exogenous latent variables in this study are two factors use of WhatsApp, namely perceived usefulness and perceived ease of use which were adopted from TAM theory. Meanwhile, the endogenous variables are employee engagement and employee performance. Measurements based on the Likert scale (1932) use numbers 1 (Strongly disagree) to 5 (Strongly agree) to obtain answers in the form of primary data.

\section{Study population and sampling}

The population used is from the employees at University of Lampung(Unila) as WhatsApp users. Employees who use WhatsApp with the same criteria and service functions from the application so that they can be used as research respondents. The number of samples is determined by taking into account the adequacy of data for the purposes of structural model analysis (SEM), especially the Partial Least Square (PLS) method. Although PLS is renowned for its ability to handle small sample sizes, it does not mean that research objectives are met with minimum sample size requirements. Many previous studies have shown that a sample size of 100 to 200 is usually a good starting point in conducting path modeling (Hoyle, 1995).

\section{Research Instrument}

Perceived usefulness is measured using 7 indicators as manifest variables that are often used in 
TAM, while perceived ease of use is measured using 3 indicators. The manifest variable for employee engagement uses 12 Gallup Q12 indicators adapted from Ariffin and Omar (2018) with WhatsApp perspective. Motyka (2018) states that several studies on employee engagement have used Gallup Q12 measurements, including: Badal and Harter (2014), Chong and Lee (2017), Dash and Muthyala (2016), Medlin and Green (2009), and Medlin etal.(2016).

Employee Performance which is used as a variable in this study is included in the process performance category (Borman and Motowidlo, 1997 in Motyka, 2018). His statement of 15 manifest indicators was adapted from the research of Koopmans and Bernaards (2014), Coole (2003), in etinkaya and Rashid, (2018), which was adapted to the perspective of using WhatsApp.

\section{Validity and reliability assessment:}

Validity Test and Reliability Test through Smart-PLS are used to measure whether the questionnaire is valid or not, and find out how accurate, consistent, and precise it is in this study.

\section{RESULTS AND DISCUSSION}

\section{Result}

A total of 142 respondents who gave responses to this study and deserve to be analyzed. The descriptive analysis is as presented in Table 1 . The age of the respondents who were most active in filling out the survey was in the range of $42-51$ years, with 52 respondents. The youngest age is 23 years old while the oldest is 62 years old.

Tabel 1. Demografi Responden

\begin{tabular}{cccc}
\hline Construct & Characteristics & Frequency & Percentage (\%) \\
\hline Gender & Male & 75 & 52.8 \\
& Female & 67 & 47.2 \\
Age & $22-31$ & 30 & 21.13 \\
& $32-41$ & 33 & 23.24 \\
& $42-51$ & 52 & 36.62 \\
& $52-61$ & 26 & 18.31 \\
Education & $>61$ & 1 & 0.70 \\
& Junior High/Senior High/Diploma & 8 & 5.6 \\
Kategori Pegawai & Bachelor (S1) & 37 & 26.1 \\
& Master (S2) & 52 & 36.6 \\
& Doctoral (S3) & 45 & 31.7 \\
\hline
\end{tabular}

Observing from the last education level, the largest group, about 36.6 percent, has a master's degree education. In the employee category, 62 percent of respondents are lecturers and the remaining 38 percent are education personnel. To find out how close the respondents are to using WhatsApp, it is presented in Table 2. Almost all of them, about 99 percent have used WhatsApp for more than two years.

Tabel 2. WhatsApp Usage

\begin{tabular}{|c|c|c|c|}
\hline WhatsApp Usage & Label & Frequency & Percentage (\%) \\
\hline \multirow[t]{3}{*}{ Using WhatsApp Since } & $<1$ year & - & - \\
\hline & $>1$ year & 1 & 1 \\
\hline & $>2$ years & 141 & 99 \\
\hline \multirow[t]{4}{*}{ WhatsApp usage per day } & $<30$ minutes & 9 & 6,3 \\
\hline & $30-60$ minutes & 29 & 24.6 \\
\hline & $60-120$ minutes & 43 & 30.3 \\
\hline & $120-180$ minutes & 55 & 38.7 \\
\hline
\end{tabular}

Based on the length of time, the majority, 38.7 percent spent between 2 to 3 hours, and only 6.3 percent used less than 30 minutes per day. WhatsApp provides the Group feature which is an important and frequently used facility. Table 3 presents data showing that 98.6 percent of respondents stated that they did join a Group, while the remaining 1.4 percent did not belong to any Group. 
Tabel 3. WhatsApp Group

\begin{tabular}{lccc}
\hline WhatsApp Group & Label & Frequency & Percentage (\%) \\
\hline Join a WhatsApp Group & Yes & 140 & 98.6 \\
& No & 2 & 14 \\
Number of WhatsApp groups & One & - & 1.4 \\
& Two & 2 & 2.1 \\
& Three & 3 & 6.3 \\
& Four & 9 & 90.1 \\
\hline WhatsApp Group Member & > Five & 128 & 97.2 \\
\hline Friends group & & & 2.8 \\
& Yes & 138 & 99.3 \\
Colleagues/Co-workers Group & No & 4 & 0.7 \\
Joint Group of Coworkers, Bosses, or Leaders & Yes & 141 & 86.6 \\
& No & 1 & 13.4 \\
Family Group & Yes & 123 & 95.8 \\
\end{tabular}

None of the respondents joined only in one group. Even the largest percentage, which is 90.1 percent or 128 respondents joined in more than 5 WhatsApp Groups. Statements regarding their joining in groups containing colleagues, work superiors, or leaders, showed that only 13.4 percent did not follow them, the remaining 86.6 percent or 123 respondents followed these groups. This study did not reach further observations regarding the reasons and mechanisms for respondents to enter a group consisting of a combination of colleagues, work superiors, or leaders. It is alleged that users can join a WhatsApp group on their own initiative, solicitation-approval, or mandatory.

The purpose or patterns of using WhatsApp by respondents are divided into six categories, as shown in Table 4.

Tabel 4. Purposes of Using WhatsApp

\begin{tabular}{ccccccc}
\hline Purposes of Using WhatsApp & TP & HTP & K & S & SS & Mean \\
\hline Work-related Affairs & 1 & 2 & 35 & 68 & 36 & 3.95 \\
Chatting (personal chat) & 1 & 2 & 43 & 65 & 31 & 3.86 \\
WA Group & 1 & 2 & 51 & 71 & 17 & 3.71 \\
Sharing (share the information) & 7 & 55 & 65 & 15 & 7 & 3.61 \\
Planning (plan on something) & 4 & 8 & 71 & 54 & 5 & 3.33 \\
Advertising & 62 & 32 & 39 & 8 & 1 & 1.97 \\
\hline
\end{tabular}

The pattern of using WhatsApp is intended to describe the habits or needs of employees in using WhatsApp on a daily basis. The biggest need to use WhatsApp is for work- related with an average score of 3.95 which is included in the high criteria. While the smallest mean value of 1.97 is found in the need for using WhatsApp to advertise which is included in the low criteria. It can be said that the daily use of WhatsApp among employees is more often used for work-related matters, in addition to other matters such as chatting, being active in WhatsApp Groups, and advertising which is very rarely done by respondents.

\section{Outer (Measurement) Model}

Construct validity test with PLS through Convergent Validity, seen from the outer loading reflective indicator. In the first estimation, found indicators that have low values on the employee performance construct, namely EP6 with a loading of 0.430, and EP7, with a loading of 0.435 . For the purposes of validity in the research model, it is known that indicators with loading factors between 0.40 and 0.70 are considered to be deleted if they can have an effect on increasing the AVE value and composite reliability of each latent construct above the recommended threshold value (Hair et al, 2013). The EP6 and EP7 indicators were decided to be deleted, even though the AVE and composite reliability values were already above the threshold, to strengthen the overall research model. The results of the 
second estimation, produce the outer loading value of all variables above 0.5 so that the convergent validity is met. Cronbach's Alpha, rho_A, Composite Reliability, and AVE values have also shown the validity of each construct, as shown in table 5.

\begin{tabular}{ccccc}
\multicolumn{5}{c}{ Tabel 5. Validity-Reliability Construct } \\
\hline Cronbach's Alpha & rho_A & Composite Reliability & AVE \\
\hline EP & 0.944 & 0.946 & 0.942 & 0.578 \\
PEU & 0.956 & 0.961 & 0.957 & 0.633 \\
PU & 0.933 & 0.937 & 0.933 & 0.824 \\
\hline
\end{tabular}

In the Average Variance Extracted (AVE) value to see the convergent validity of the research construct, each construct value is: EE (0.578), EP (0.633), PEU (0.824), PU (0.742). The AVE value of all constructs shows numbers above 0.50 , thus the convergent validity for the constructs in this study has been fulfilled.

The results of the estimation of the Discriminant Validity aspect shown by the Cross Loading value of all indicators in each indicator of PU, PEU, EE, and EP are higher for the construct of its association, compared to other constructs, so that it can be indicated that the measurement of this model cross loading has met the criteria of good discriminant validity. In addition, the value of the heterotraitmonotrait correlation ratio shows that the HTMT correlation ratio is all below 0.85 which means that the discriminant validity requirements have been met.

The reliability of the latent variables of this study, as shown in Table 6, the value of Cronbach's Aplha and composite reliability for all constructs has been above 0.70 . Thus, all constructs have good reliability in accordance with the minimum required value limit.

\section{Structural Model Test (Inner Model) and Hypotheses}

In the test results of the Determination coefficient (R-Square) which is displayed on Table 8, the value of the R Square for EE is 0.631 which means that the PU and PEU variables are simultaneously able to explain their effect on the EE construct of 63.1 percent.

\begin{tabular}{cc} 
Tabel 8. Determination Coefficient (R-Square) \\
\hline & R Square \\
\hline EE & 0.631 \\
EP & 0.540 \\
\hline
\end{tabular}

It can be said that the changes in employee engagement among employees through the use of WhatsApp, about 63.1 percent came from the contribution of those two constructs. The remaining 36.9 percent is explained by other variables that we did not observe. Meanwhile, in the endogenous EP construct, the R square value is 0.540 , which means that the PU and PEU variables are simultaneously able to explain the effect on the EP construct by 54 percent while the remaining 46 percent is explained by other variables outside this research model. It means, the PU and PEU are 2 factors that significantly influence changes to EE and EP among employees. Next, looking at the predictive relavance of this study from the Q2 value. The value generated from the test is 0.830 which means this research has high predictive relevance because it is close to 1 .

In the observation of the Goodness of Fit (GoF) value in Table 9., the SRMR value of 0.068 indicates the model has met (fit), because the structural equation model can be said to be accepted if the SRMR value is $<0.08$ (Benitez, 2019).

\begin{tabular}{lcc}
\multicolumn{3}{c}{ Tabel 9. Goodness of Fit (GoF) Value } \\
\hline SRMR & Saturated Model & Estimated Model \\
Chi-Square & 0.068 & 0.068 \\
NFI & $1,610.910$ & $1,610.910$ \\
\hline
\end{tabular}

The Chi-square value obtained is 1,610.910, then the empirical data use in this study is very identical to the theory used, because the Chi-square should have a range of values $>0.05$. The NFI (Normed Fit Index) value is 0.703 , which indicates a good model, because the range of good values is NFI 
$<0.90$. From the results of the SRMR, Chi-square and NFI values, the model in this study is considered fit, from the observation of the effect of latent constructs based on outer model and inner model testing, Table 10 describes the results of the algorithm on the PLS-SEM Path Coefficiens section.

Tabel 10. Path Coefficient between Constructs

\begin{tabular}{ccccc}
\hline $\mathbf{(} \boldsymbol{\alpha}=\mathbf{0 . 0 5}$; two-tailed test ) & Original Sample (0) & Standard Deviation (STDEV) & T Statistics (|0/STDEV|) & P Values (Sig. 0.05) \\
\hline PU -> EE & 0.625 & 0.083 & 7.550 & 0.000 \\
PEU -> EE & 0.224 & 0.099 & 2.271 & 0.024 \\
PU -> EP & 0.177 & 0.143 & 1.243 & 0.215 \\
PEU -> EP & 0.494 & 0.107 & 4.614 & 0.000 \\
EE -> EP & 0.138 & 0.131 & 1.050 & 0.294 \\
\hline
\end{tabular}

Discussion

Perceived Usefulness on Employee EngagementPerceived Ease of Use on Employee Engagement.

$\mathrm{H} 2$ is accepted, statistically significant supported by empirical data through the path coefficient value of 0.224 , the t-statistic value of 2.368 , and the P-value of 0.018 , then the significance is fulfilled in direct influence between perceived ease of use and employee engagement. Thus, it can be stated, the easier it is to use WhatsApp in the working environtment at workplace, the more employee engagement through WhatsApp will increase.

This finding is in accordance with the statement in TAM, that the ease of a technology will lead to a belief about the decision-making process to use a technological system with less effort (Davis, 1989). The use of the system will lead to being engaged in workplace. Research by Ariffin and Omar (2018) also produces the same conclusion that the most influential factor in the acceptance of WhatsApp use among employees is perceived ease of use which affects employee engagement. Similar results were also found in the research of Latib et al. (2014) in a study of the use and functionality of Facebook as a predictive factor, where perceived ease of use proved to be significant as a predictor of employee engagement. Research by Dzandu et al. (2016) also produced the same findings, perceived ease of use was proven to be significant as a predictor in the use of social media among university students.

The researcher observed the statistical data on the age distribution of WhatsApp users (Table 1), employees at the millennial age range from 22-40 (in 2019) spread over two age ranges. In the age range of 22-31 with a number of 21.13 percent and the range of 32-41 with 23.24 percent users so that a total of 44.37 percent of respondents. This generation will play an important role in empowering the use of social media systems for organizational performance. If the leadership is able to make them more engaged with their work through the use of information systems such as WhatsApp, then the projected vision and mission achievement through the productive performance of employees in the future is expected to be fulfilled.

Employee engagement really needs to be managed seriously when it comes to the use of internet technology by millennials. According to Hughes et al. (2012), millennial employees who enter the world of work will tend to look for the teams with the same vision, security, and balance with their youth. Millennial employees are the internet generation (digital natives) who will bring into the workplace sharing habits born of their extensive experience with social media. They are the one who will determine the future of the campus by their mastery of social technology.

Stakeholders at university who already know the importance of social media, need to pay more attention to this aspect. Rowan-Kenyon (2016) states that the future of social media on campus is the future of social media itself. The ease of use of WhatsApp is perceived to help reduce effort at work, rather than those who are not using it. It is generally recognized that younger employees tend to be more techsavvy than their older counterparts. More and more young employees, both lecturers and education staff, who hold roles as first-line supervisors or middle-level management positions, require effective communication and collaboration with their seniors. Because there is a strong relationship between the reaction and performance of older workers and the age difference of younger leaders (Hughes, 2012).

Perceived Usefulness on Employee Performance. 
In contrast to employee engagement, it turns out that perceived usefulness does not directly affect employee performance. The path coefficient value is 0.177 , and the t-statistic value is 1.255 , but the Pvalue of 1.210 is less than 0.05 , so $\mathrm{H} 3$ is rejected because it is not significant. There is no direct effect of perceived usefulness with employee performance in using WhatsApp. It can be stated that the more useful WhatsApp at work, it does not directly increase employee performance.

This result is different from the research of Çetinkaya and Rashid (2018) which shows the usefulness of social media is highly correlated and contributes on improving job performance. However, the research results of Nugroho et al. (2018) who used TAM to research the use of e-learning among students, also did not find a significant effect of perceived usefulness on the performance of users, same as this study. Quoted from Hartono J. (2007), several studies with TAM also yielded the same conclusion, such as Chow and Leitch (1997) not finding a relationship between perceived usefulness and attitudes to using an information system. Jackson et al. (1997), Lucas Jr and Spitler (1999), also did not find empirical evidence that supports the relationship between perceived usefulness and behavioral intentions to use an information system. Studies by Jones (2010), and Muchran (2015) also did not find a significant effect of perceived usefulness on behavioral interest in using information systems.

Therefore, the perceived usefulness construct has the possibility to not being able to predict the attitudes, intentions, and behavior of using information technology. In those conditions, it may be due to a different research context from when the perceived usefulness construct was developed (Abdillah and Hartono, 2018).

WhatsApp in this study is used as a medium or tool to predict the influence of its use on employee performance. It is suspected that there are other factors in the acceptance of the use of WhatsApp technology that affect employee performance. Modification of variable indicators, use of other technology acceptance variables, use of other technology evaluation models such as Task-Technology Fit, or with other research method approaches may result in opposite empirical calculations.

\section{Perceived Ease of Use on Employee Performance.}

The construct of perceived ease of use is proven to have a direct effect on employee performance with empirical data path coefficient value of 0.494 , the t-statistic value of 4.538 and the P-value of 0.000 , then the significance is fulfilled. Therefore, it can be stated that the easier it is to use WhatsApp at work, the more employee performance will improve.

In line with the research of Omar et al. (2019) which shows a significant relationship with the effect of perceived ease of use on Employee Performance. Likewise, the research by Kassim et al. (2018) which empirically shows that perceived ease of use together with perceived usefulness in using WhatsApp has a significant and positive relationship with employee performance.

When viewed from the respondent's descriptive on participation in WhatsApp groups, 99.3 percent admitted joining a group containing their colleagues at the office. The existence of interpersonal and collective communication within the group can be exchanged without formal boundaries, and creates mutual intimacy. This allows each member to determine the plan and implementation method of a task, even remembering it without having to receive direct notification face-to-face. The ease of collaboration has an impact on maintaining employee performance by using WhatsApp. The statement of perceived ease of use regarding the ease of learning how to use, ease of interaction, and liking for using WhatsApp is an element that influences employees to use it for various purposes.

\section{Employee Engagement on Employee Performance.}

In this study, the H5 statement was rejected, because the test showed the path coefficient value of 0.138 , the t-statistic value of 1.068 , and the P-value of 0.285 , then the significance was not met. Thus, it can be stated that in the use of WhatsApp among employees, that the employee engagement does not necessarily improve employee performance.

In this study, there is no effect of employee engagement on employee performance through the use of WhatsApp. In several studies that use HR factors, it is proven that employee engagement has an 
effect on employee performance. For example, the study of Anitha (2014) and Azizah (2015), it is stated that employee engagement has a significant impact on employee performance. WhatsApp through perceived usefulness and perceived ease of use in this study is used estimate the influence of both constructs on employee employee engagement and employee performance. Developments in different studies, research frameworks, samples, and analytical methods can allegedly lead to the opposite conclusion.

\section{CONCLUSION}

The Overall analysis results in this study produce a suitable model to show that the two main constructs in the Technology Acceptance Model (TAM) theory, namely Perceived Usefulness and Perceived Ease of Use of WhatsApp, are suitable to be used to examine their effect on Employee Engagement and Employee Performance. The use of WhatsApp that was studied using both constructs was proven to significantly affect employee engagement. Therefore, according to Parry and Solidoro (2013) who revealed that social media is currently becoming one of the suitable mechanisms for realizing engagement. The conclusions in this study provide an overall picture with the following result points:

1. The use of WhatsApp through the latent construct of perceived usefulness has the highest positive effect on employee engagement. The more useful WhatsApp is at work, the more engagement will increase through the use of WhatsApp by employees.

2. The more useful WhatsApp is at work, it does not directly increase employee performance through the use of WhatsApp by employees.

3. The easier it is to use WhatsApp at work, the more engagement will increase through the use of WhatsApp by employees.

4. The easier it is to use WhatsApp at work, the more it will increase the employee performance through the use of WhatsApp by employees.

5. With the use of WhatsApp, the existence of employee engagement does not necessarily increase the employee performance of employees.

\section{REFERENCE}

Abdillah, W., Hartono, J. 2015. Partial Least Square (PLS) : Alternatif Structural Equation Modeling (SEM) dalam Penelitian Bisnis. Andi. Yogyakarta.

Agrawal, S.R., Mittal, D. 2019. Constructive Usage of WhatsApp in Education Sector for Strengthening Relations. International Journal of Educational Management Vol. 33 No. 5, 2019 pp. 954964.

Azizah, A., Gustom, A. 2015. The Influence of Employee Engagement To Employee Performance At PT Telkom Bandung. Journal Of Business And Management, Vol. 4, No.7, 2015: pp. 817-829.

Anitha, J. 2014. Determinants of employee engagement and their impact on employee performance. International Journal of Productivity and Performance Management. Vol. 63 Issue: 3, pp.308323.

AON. 2018. Trends in Global Employee Engagement, Global Employee Engagement Rebounds to Match Its All-Time High. Retrieved From AON Website: https://insights.humancapital.aon.com. (2019, April 22)

Ariffin, Z., and Omar, S. Z. 2018. Usage of WhatsApp in Relation to Employee Engagement in a Telecommunication Company. International Journal of Academic Research in Business and Social Sciences, 8(1), 434-452.

Aulia, E. D. 2018. Analisis Faktor Penerimaan Dan Penggunaan Teknologi Dengan Menggunakan Technology Acceptance Model (Tam) Pada Pengguna Instant Messaging WhatsApp. e-Proceeding of Management: Vol.5, No.1. Bandung.

Byrne, Z. S. 2014. Understanding Employee Engagement: Theory, Research, and Practice.

Retrieved From http://books.google.co.id. (2019, January 22).

Byrne. O., and MacDonagh, J. 2017. What's Love Got to Do with It? Employee Engagement Amongst Higher Education Workers. The Irish Journal of Management, 36(3), 189-205.

Cao, X., Guo, X., Vogel, D. and Zhang, X. (2016), "Exploring the influence of social media on employee 
work performance", Internet Research, Vol. 26 No. 2, pp. 529-545.

Çetinkaya, A.S., and Rashid, M. 2018. The Effect of Use of Social Media on Employee Job Performance. Journal of Internet Application and Management: 2018 / 9 (2).

Church, K., and Oliveira, R. De. 2013. What's up with WhatsApp ? Comparing Mobile Instant Messaging Behaviors with Traditional SMS. Proceeding of Mobile HCI 2013-Collaboration and Communication. Munich Germany (pp 352-361).

Counts, S. 2007. Group-Based Mobile Messaging in Support of the Social Side of Leisure.

Computer Supported Cooperative Work (CSCW), 16(1-2), 75-97.

Davis, F.D. 1989. Perceived Usefulness, Perceived Ease of Use, and User Acceptance of Information Technology. MIS Quarterly 13(3). 319-340.

Dzandu, M.D., Boateng, H., Agyemang, F.G. 2016. Social Media Adoption Among University Students: The Role Of Gender, Perceived Usefulness and Perceived Ease Of Use. Int. J. Social Media and Interactive Learning Environments, Vol. 4, No. 2.

Ewing, M., Men L. R., O’Neil, J. 2019. Using Social Media to Engage Employees: Insights from Internal Communication Managers, International Journal of Strategic Communication. 13:2, 110-132.

Gallup. 2017. State of the Global Workplace. The Gallup Organization Ltd. Retrieve From Gallup Feature Report: https://www.gallup.com/workplace/238079/state-global- workplace-2017.aspx. 215. (2019, February 12)

Goodhue, D., \& Thompson, R. L. 1995. Task-technology fit and individual performance.

MIS Quarterly, 19, 213-236.

Hair, Joseph F. and Ringle, Christian M. and Sarstedt, Marko. 2013. Editorial - Partial Least Squares Structural Equation Modeling: Rigorous Applications, Better Results and Higher Acceptance. Long Range Planning, Volume 46, Issues 1-2, pp. 1-12.

Hartono, J. 2007. Sistem Informasi Keprilakuan. Andi. Yogyakarta.

Hughes, Ginnet, Curphy. 2012. Leadership: Enhancing the Lessons of Experience. Ninth Edition. McGrawHill Education. New York.

Isaac, O., Abdullah, Z., Ramayah, T., M. Mutahar, A., \& Alrajawy, I. 2016. Perceived Usefulness, Perceived Ease Of Use, Perceived Compatibility, And Net Benefits: An Empirical Study Of Internet Usage Among Employees In Yemen. 7th International Conference On Postgraduate Education, Pp. 899-919. Malaysia.

Jung, Y.Y., Sembiring, S. 2019. Pengaruh Employee Engagement Terhadap Kinerja Karyawan BPJS Ketenagakerjaan Bandung Raya. E-Proceeding of Management: Vol 6, No (2019). Telkomn University. Bandung

Kahn, W.A. 1990. Psychological conditions of personal engagement and disengagement at work'. Academy of Management Journal, 33: 4, 692-724.

Kassim, N.H. 2018. Impact Of Perceived Usefulness, Perceived Ease Of Use And Behavioral Intention In Using WhatsApp Towards Job Performance. Conference Paper. Teknologi, Universiti \& Cawangan, Mara \& Kampus Samarahan, Sarawak \& Meranek, Jalan.

Koopmans, L. Buuren, S. V., and Beek, A. J. v. d. 2013. Development of an Individual Work Performance Questionnaire. International Journal of Productivity and Performance Management, 62(1), 6-28.

Macey, W.H. and Schneider, B. 2008. The Meaning of Employee Engagement. Industrial and Organizational Psychology. Vol. 1 No. 1, pp. 3-30

Mangkunegara, A., P. 2006. Perencanaan dan Pengembangan Manajemen Sumber Daya Manusia. PT Refika Aditama. Bandung.

May, D.R., Gilson, R.L., Harter, L.M. 2004. The Psychological Conditions of Meaningfulness, Safety and Availability and The Engagement of The Human Spirit At Work. Journal of Occupational and Organizational Psychology (2004), 77, 11- 37.

Men, L.R., O'Neil, J., Ewing, M. 2020. Examining the effects of internal social media usage on employee engagement. Public Relations Review, Volume 46, Issue 2,2020.

Motyka, B. 2018. Employee Engagement and Performance: A Systematic Literature Review. International Journal of Management and Economics. 54(3): 227-244.

Muchran, M. 2015. Acceptance of Banking Information Technology in PT BNI of Makassar. Journal of Economics and Behavioral Studies, 7(2(J), pp. 124-130. Doi:10.22610/jebs.v7i2(J).570

O'Hara et al. 2014. Everyday dwelling with WhatsApp. Proceedings of the 17th ACM conference on Computer supported cooperative work \& social computing, pp. 1131- 1143. 
Obar, Jonathan A., Wildman, S. (2015). "Social media definition and the governance challenge: An introduction to the special issue". Telecommunications Policy. 39 (9): 745-750. doi:10.1016/j.telpol.2015.07.014

Omar, N., Munir, Z. A., Kaizan, F. Q., Noranee, S., and Malik, S. A. 2019. The Impact of Employees Motivation, Perceived Usefulness and Perceived Ease of Use on Employee Performance among Selected Public Sector Employees. International Journal of Academic Research in Business and Social Sciences, 9(6), 1128-1139.

Parry, W. \& Solidoro, A. 2013. Social Media as a Mechanism for engagement? Social Media in Human Resources Management Advanced Series in Management, 121-141. Doi: 101108/S18776361(2013)0000012010.

Pradhan, R.K. and Jena, L.K. 2017. Employee Performance at Workplace:Conceptual Model and Empirical Validation. Business Perspectives and Research 5(1). 69-85. K.J. Somaiya Institute of Management Studies and Research.

Rowan-Kenyon, H., Alemán A. M., Gin, K., Blakeley, B., Gismondi, A. Lewis, J., McCready, A., Zepp, D., Knight, S. 2016. Social Media in Higher Education. ASHE Higher Education Report. 42. 7128. 10.1002/aehe.20103.

Sago, B. 2013. Factors Influencing Social Media Adoption and Frequency of Use: An Examination of Facebook, Twitter, Pinterest and Google+. International Journal of Business and Commerce Vol. 3, No.1.01-14.

Similarweb.com. 2019. Mobile Messaging App Map of the World - January 2019. Retrieve From Market Inteligent Blog: https://www.similarweb.com/blog/mobile-messaging-app- map-january-2019. (2019, 2 February)

Statista.com. 2019. Number of daily active WhatsApp Status users from 1st quarter 2017 to 1st quarter 2019 (in millions). Retrieve From https://www.statista.com/statistics/. (2019, April)

Turban E., Volonio L., Wood G.R. 2015. Information Technology for Management: Digital Strategies for Insight, Action, and Sustainable Performance. Wiley. New Jersey.

Wearesocial and Hootsuite. 2019. Digital 2019 Indonesia. All The Data And Trends You Need To Understand Internet, Social Media, Mobile, And E-Commerce Behaviours In 2019.

Retrieve From https://wearesocial.com/blog/2019/01/digital-2019-global- internet-use- accelerates. (2019)

WhatsApp.com. 2019. Simple. Secure. Reliable messaging. Retrieve From http://www.WhatsApp.com. (2019, April). 